\title{
Social Problems in Turkish Social Studies Coursebooks and Workbooks
}

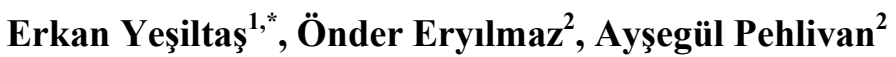 \\ ${ }^{1}$ Faculty of Education, Cumhuriyet University, Turkey \\ ${ }^{2}$ Faculty of Education, Anadolu University, Turkey
}

Copyright $\mathrm{O} 2016$ by authors, all rights reserved. Authors agree that this article remains permanently open access under the terms of the Creative Commons Attribution License 4.0 International License

\begin{abstract}
In Turkey, the social studies course, which is taught in elementary $5^{\text {th }}$ to $7^{\text {th }}$ grades, prepares students to solve problems they may encounter in their future life. Therefore, the teaching of social problems to help students get to know them is one of the most important issues for the social studies course. The primary aim of this study is to examine how social problems are included in the social studies coursebooks and workbooks. $5^{\text {th }}, 6^{\text {th }}$ and $7^{\text {th }}$ grade social studies coursebooks and workbooks were analysed in the study. Document analysis method, which is one of the qualitative research methods, was used in data analysis. The findings of the study showed that the coursebooks and workbooks of the Ministry of National Education included and emphasized more social problems than those of the private publishing companies. Based on the findings, it is suggested that social studies coursebooks and workbooks published by private publishing companies should be modified in such a way that they include and emphasize more social problems.
\end{abstract}

Keywords Social Problems, Social Studies, Coursebooks, Workbooks

\section{Introduction}

As a social entity, humans have struggled to survive since their existence, and tried to find solutions to social problems they encountered in this process in different ways. The solution of these social problems brought new developments that led to the emergence of other social problems. This cause-effect relationship has always been there during the history of human race, and human beings had to cope with a set of social problems that affect them constantly.

Although the concept of social problem has a long history, there has not been an agreement on its definition and the concept was defined in various ways from different perspectives in the historical process $[5,42]$. In this regard, the theorists who adopted the social conflict theory define social problem as the issues that emerge as a result of the pressure of a class created by the capitalist system and that possesses the economic power on another class, whereas feminist theorists view it as the pressure that men create on women. On the other hand, while symbolic interactionists define social problem as the meaning humans attach to events, constructivists define it as the situations by which a group or community claims they are affected based on objective data and subjective views. Functionists who carried out evaluations on this topic approach social problem as negative situations that a mechanism functioning within the social order affects $[5,19,22,23,27,30]$. Based on these definitions, social problems can be defined as issues that affect one or more groups in the society, and have one or more solutions. In other words, social problems are related to various environments that form the wider structures of social and historical life as a whole and have an influence on each other in an intertwining way [2, 40].

Societies try to solve the social problems that they experience within by means of various channels. In order to cope with social problems encountered, one of the most effective ways to apply is education. As a social organisation, education has a balancing function that helps solving social problems [47]. Educational institutions aim to equip individuals with skills to cope with problems that they encounter starting from the first stage of education.

One of the courses in the education system that aim to teach individuals to be sensitive to social problems and the skills to cope with these problems is the social studies course. Within the scope of the social studies course that is taught in the elementary education stage and is an interdisciplinary course based on social sciences, individuals are trained to be active citizens who are sensitive to social problems by teaching them a set of knowledge, skills and values [26].

Social studies is a course that aims to help individuals realize their social existence, reflects social sciences such as history, geography, economy, sociology, anthropology, psychology, philosophy, political science and law as well as citizenship knowledge. It is also a course that involves combining learning areas under a unit or theme, and 
examines human's interaction with the social and physical environment, and is formed based on the understanding of public education [26]. It is taught by elementary school teacher in $4^{\text {th }}$ grade, and by social studies teachers in $5^{\text {th }}, 6^{\text {th }}$ and $7^{\text {th }}$ grades. The social studies curricula have been prepared in a spiral structure by adopting a constructive approach. In the curricula, there are outcomes, learning areas, skills, concepts, values, activity samples, intermediate disciplines, and the associations among these. Social studies and elementary school teachers carry out the lessons in accordance with the explanations included in the social studies curricula and teacher's books.

As a topic, social problems constitute an important place in the contents of the social studies course. As a matter of the fact, the statements "believes in the important of participation, suggests original views on the solutions of personal and social problems" and "Teacher should confront students with real-life problems and contradictory situations frequently and make them reflect on the social problems they encounter by using the events in and outside the school." included among the overall aims of the social studies curricula, and the explanations related to the implementation of the curricula, respectively, reveal that there is a close relationship between the concepts of social problem and social studies. [26]. In addition, the skills of "dealing with social problems in the environment individually or in cooperation with other, and developing and implementing projects that would contribute to the solution of these problems" are aimed to be taught with regard to social participation as one of the target skills in the social studies curricula [26]. These outcomes and skills that are given in the curricula also show that it is important to define social problems and raise individuals' awareness in this respect.

In the social studies curricula prepared in 2005 , there are explanations related to including social problems in the course [26]. This shows that social problems are of importance for the social studies course. Social studies teachers deliver these issues to students through various ways. One of these ways is the use of social studies coursebooks and workbooks. Coursebooks and workbooks are the primary resources that contribute to student learning and help teachers in the teaching process, and continue to be irreplaceable for teachers despite the developing technology in the last decades $[36,39]$. In this regard, it is of significance that coursebooks and workbooks should be prepared in accordance with the curricula accepted by the Ministry of National Education, and that they should include the knowledge, skills and values that are aimed to be taught to individuals $[4,10]$.

In the literature, there are studies on social problems, and these studies focus on student attitudes and views regarding social problems as well as the social problems that disabled individuals and those who are not disabled are exposed to [15, $20,16,33,37]$. Besides, there are experimental studies investigating the effect of various variables on sensitiveness to social problems, strategy and scale development studies related to the teaching of social problems, and documentary analysis studies on the concepts that are regarded as social problems $[1,3,12,21,24,32,43,46]$. There are also studies on social problems carried out in the fields of medicine [16, $17,49]$, sociology [ $7,8,13,14,18,25,29,31,34,35,38,45$, 48] and psychology [11]. On the other hand, social studies teachers conduct their lessons in accordance with the outcomes stated in the social studies curricula prepared by the Ministry. Therefore, how social problems are included in the social studies curricula apart from the coursebooks and workbooks is another topic of interest. From this perspective, it seems to be of significance to examine the social problems in the social studies coursebooks and workbooks. This study aimed to examine how social problems are included in the social studies coursebooks and workbooks used at middle school level in Turkey. Answers for following questions will be sought after towards this aim:

1. How are social problems included in the middle school social studies coursebooks and workbooks published by private publishing companies in Turkey?

2. How are social problems included in the middle school social studies coursebooks and workbooks published by the Ministry of National Education in Turkey?

\section{Method}

In the study, the documentary analysis method, which is a qualitative research method, was used since the social studies coursebooks and workbooks published by the Ministry and private publishing companies were to be examined. Documentary analysis refers to a systematic process conducted to examine and evaluate printed and electronic documents [50]. It has a set of steps as accessing documents, checking the originality of the documents, understanding the documents, analysing the data, and using the data.

Because there are different definitions of social problem suggested by various paradigms, the paradigm of the study was to be determined before accessing the documents. In this regard, objectivism, which has a definition of social problem that is conceptually clearer in scope, formed the paradigm of the study. According to the objectivist perspective, social problems are social situation that are based on a set of values and scientific judgements, and damage social welfare [28]. Therefore, this definition was adopted in the study.

In the study, all coursebooks that were available through the official website of the Ministry and were taught in the 2015-2015 school year were initially accessed. In Turkey, the social studies coursebooks published by both the Ministry and private publishing companies are distributed to students free of charge. The coursebooks to be distributed are decided by the Ministry's Board of Education and Discipline. The social studies and elementary school teachers inform the administration of their schools about the coursebooks that 
they have determined among those decided by the board, and the school administrations notify the board about their teachers' choice. The coursebooks that were decided to be distributed for the social studies course in the 2011-2016 school year included the $5^{\text {th }}$ grade social studies coursebooks and workbooks published by Evren Publishing, the $6^{\text {th }}$ grade social studies coursebooks and workbooks published by Yakın Çağ Publishing, the $7^{\text {th }}$ grade social studies coursebooks and workbooks published by Tuna Printing, and the $6^{\text {th }}$ and $7^{\text {th }}$ grade social studies coursebooks and workbooks published by the Ministry. The obtained documents were analysed using the content analysis technique, which is a qualitative research method. In content analysis, researchers aim to identify the occurrence of certain words or concepts in a dataset consisting of a text or texts in an objective and systematic way, and then to make inferences based on these identifications [9]. In this way, the documents obtained in the study were analysed using content analysis by taking into consideration the definition of social problem. Certain codes were reached in the analysis, and these codes were combined into themes. The data were presented and interpreted in accordance with the research questions of the study.

In order to enhance the trustworthiness of the study, $20 \%$ of the data analysed by the researchers were also analysed by an independent field expert. Barber and Walczak [6] state that $20 \%$ of the data being coded by a different field expert independently and the agreement at which the researchers and the experts coding the data independently reach enhance the trustworthiness of a qualitative study with regard to data analysis. The researchers and the experts coding the $20 \%$ of the data compared their analyses, and there was a negotiation regarding the data until an agreement was reached on the findings. Consequently, the themes were finalised and the findings were revealed.

\section{Findings}

\subsection{Findings on the Coursebooks and Workbooks of Private Publishers}

\subsubsection{Findings on $5^{\text {th }}$ grade coursebook and workbook}

In the $5^{\text {th }}$ grade social studies coursebook, it was found that social problems were included in five units, being "I learn My Rights", "Turkey, Step By Step", "Let's Learn About Our Region", "Workers For the Society", and "One Country, One Flag", but the rest of the units did not include any topics related to social problems.

Based on the social problems found in the $5^{\text {th }}$ grade social studies coursebook, four themes, which are education, health, natural disasters and environmental problems, were revealed. While education and health were given directly as a social problem, the themes of natural disasters and environmental problems touched upon social problems mostly experienced as a result of these themes. In other words, it can be stated that natural disasters and environmental problems were not regarded as social problems, but they involved social problems that were experienced due to natural disasters and environmental problems. As for the $5^{\text {th }}$ grade social studies workbook, it included activities related to the themes of education, natural disasters and environmental problems within the same units with the coursebook, but there were no activities related to the health theme in the workbook, and five activities related to these three themes were included.

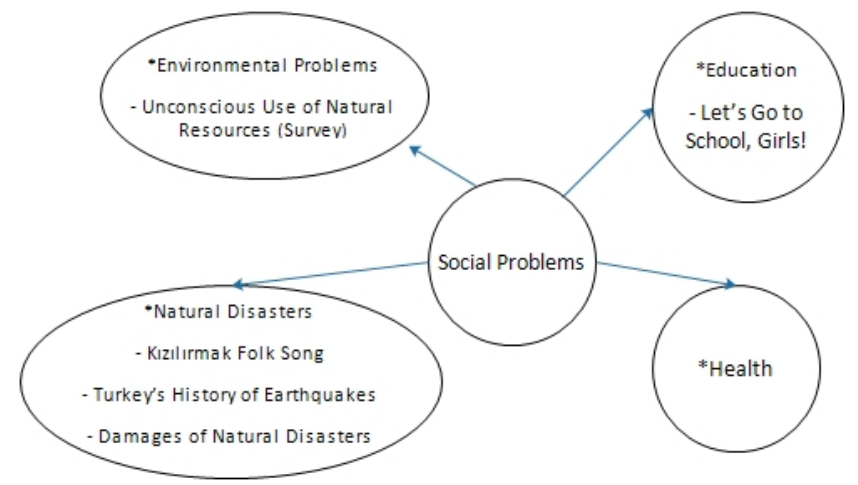

Figure 1. Social Problems Included in the $5^{\text {th }}$ Grade Coursebook and Workbook

In the $5^{\text {th }}$ grade social studies coursebook, girls' not being sent to school, the imbalance in the literacy rates of women and men, lack of interest in reading and the education of disabled individuals were mentioned as social problems. These topics were evaluated under the theme of education. Whereas girls' not being sent to school and lack of interest in reading were directly shown as social problems in the coursebook, the imbalance in the literacy rates of women and men was given related to Atatürk's revolutions in the unit "I Learn My Rights", and the problems individuals experienced in this respect were explained. With regard to the education of disabled individuals given in the unit "One Country One Flag", the difficulties disabled individuals and their families had were included as well as the solutions implemented for these problems. As for the 5th grade workbook, the activity "Let's Go to School, Girls!" was included about education in the unit "I Learn My Rights".

The topics of using drugs harmful to health, traffic accidents and contagious diseases, which were shown as social problems, were evaluated under the health theme. In the unit "Turkey, Step By Step" of the coursebook, it was mentioned that many people died due to contagious diseases by referring to the diseases experienced in the years of war by saying "We lost more people from contagious diseases like measles, cholera and tuberculosis than we did in the War of Independence" (p. 41). Students were asked to prepare projects providing solutions for the problems regarding the use of drugs harmful to health and traffic accidents in the unit "I Learn My Rights". However, no activities related to the health theme were included in the 5th grade workbook.

The topics of weather events, environmental pollution, unconscious use of natural resources and global warming, 
which were given as social problems in the 5th grade coursebook, were evaluated under the theme of environmental problems. The news presented under the title "Snow barrier to education" in the unit "Let's Learn About Our Region" of the 5th grade coursebook reads as follows:

Due to the snowfall that has affected Kütahya for the last three days, education is suspended in the schools located in the city centre and the districts of Altıntaş, Dumlupınar and Hicarcik as well as the elementary schools with mobile education located in Emet and Çavdarhisar districts. The snowfall also caused the closure of 330 village roads in the districts of Altıntaş, Dumlupınar, Aslanapa, Emet and Çavdarhisar [51].

This excerpt can be shown as an example to social problems that the local community experienced in transportation and education due to the snowfall. In the same unit of the $5^{\text {th }}$ grade workbook, a survey activity related to the unconscious use of natural resources was also included with regard to the theme of environmental problems.

With respect to the theme of natural disasters, it included the difficulties and problems that masses had following the disasters that happened in Turkey such as erosion, earthquake, snow slide, flood and fire In addition, those disasters that happened outside Turkey, such as the earthquake in Pakistan and the tsunami in Japan, were also mentioned. In the coursebook, a piece of news titled "5 Million Affected" telling the earthquake in Pakistan and the following social and economic problems were presented.

As a result of the rainfalls in September and October, 240 people are dead in the floods which engulfed the Sind Province in southern Pakistan, and more than 5 million had to leave their homes. In the region where 700 thousand houses were damaged due to the floods, agriculture and stock breeding, which are vitally important for the country's economy, got a severe blow. 1,5 million hectares of farmland were submerged, 688 thousand hectares of cultivated land were damaged, and hundreds of thousands of small and large animals perished [51].

In the unit "Let's Learn About Our Region" of the $5^{\text {th }}$ grade workbook, activities mentioning the damages of natural disasters and Turkey's history of earthquakes were given along with the "Kizllirmak Folk Song" under the theme of natural disasters [52].

\subsubsection{Findings on $6^{\text {th }}$ grade coursebook and workbook}

In the $6^{\text {th }}$ grade social studies coursebook, social problems were mentioned in five units, being "Life on Earth", "Turks on the Silk Road", "Our Country's Resources", "Our Country and the World", and "the Electronic Century", while the rest of the units did not include any reference to social problems.

Based on the social problems found in the $6^{\text {th }}$ grade social studies coursebook, four themes, which are environmental problems, health, natural disasters and violation of human rights, were revealed. While the issues evaluated under the themes of environmental problems, health and violation of human rights were given directly as social problems, those evaluated under the theme of natural disasters referred to social problems occurred due to natural disasters. In this regard, it can be stated that the theme of natural disasters was not included in the coursebook as a social problem by itself, but the difficulties experienced as a result of natural disasters were considered as social problems. As for the $6^{\text {th }}$ grade social studies workbook, it included activities related to the themes of environmental problems, health and wage theft within the same units with the coursebook, but there were no activities related to the theme of natural disasters in the workbook, and six activities related to these three themes were included.

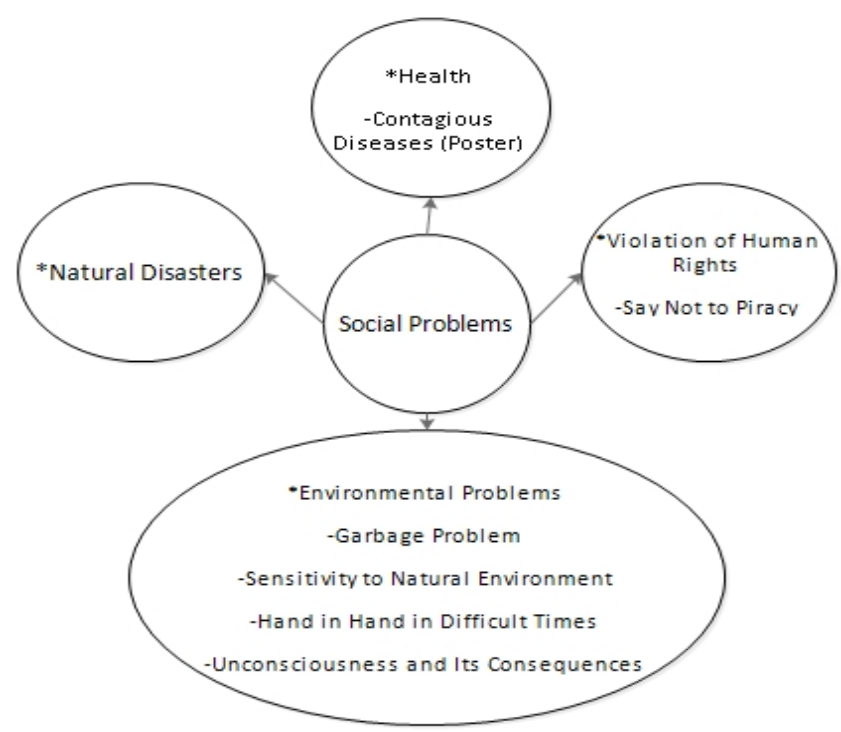

Figure 2. Social Problems Included in the $6^{\text {th }}$ Grade Coursebook and Workbook

Environmental problems was one of the themes revealed based on the social problems identified in the 6th grade coursebook. In the coursebook, the social problems related to environmental pollution, unconscious use of natural resources and extinction of species were evaluated under the theme of environmental problems. The statements in the 6th grade coursebook such as "excessive hunting of seals and whales at the poles causes the danger of their extinction" (s. 39) can be shown as examples of the social problems that can emerge related to environmental problems. In addition, in the unit "Our Country's Resources" of the coursebook, a reading text titled "The ecological problems caused by the tanker accident" explained how a tanker accident happened in the Black Sea affected the lives of species [53]. In the 6th grade workbook, activities which are designing projects, preparing posters to improve sensitivity to environment, and "Hand in hand in difficult times" for environmental pollution were included in the units "Life on Earth", "Our Country's Resources", and "Our Country and the World".

Environmental problems were another theme revealed based on the social problems identified in the 6th grade 
coursebook. Under this theme, social problems related to contagious diseases were included. With regard to contagious diseases in the unit "Electronic Century" of the coursebook, diseases such as AIDS, bird flu, swine flu, typhoid, tuberculosis and hepatitis B-C, and the destruction caused by these diseases on human body were mentioned. Besides, while presenting historical issues in the unit "Turks on the Silk Road", it was also mentioned that contagious diseases are so important as a social problem that they can force people to emigrate. As for the unit "Electronic Century" in the 6th grade workbook, it included a poster activity titled "Contagious diseases".

The last theme revealed in the $6^{\text {th }}$ grade coursebook was natural disasters. In the coursebook, the difficulties and problems that masses experience after the natural disasters in Turkey and the world such as erosion, earthquake and fire. In the unit "Our Country and the World" of the coursebook, it was highlighted that the problems experienced had a cause-effect relationship with each other by mentioning that some of the natural disasters happened in Turkey were due to the unconscious use of natural disasters and these disasters caused deaths. In addition, the earthquake in Pakistan and the tsunami in Japan were mentioned under the topic "The Whole World Hand in Hand" and these pieces of news were the same with the $5^{\text {th }}$ grade coursebook. However, no activities related to the theme of natural disasters were found in the $6^{\text {th }}$ grade workbook.

Under the theme of the violation of human rights, the topic "Anti-Piracy" was included, and it was emphasised that unauthorised reproduction of copyright material does not only have serious damages to individuals but also to the state in terms of economy, and this is one of the important problems in Turkey lately. With respect to this theme, in the same unit of the $6^{\text {th }}$ grade workbook, an activity titled "Say No to Piracy" was included, and students were asked to prepare a poster on this topic [54].

\subsubsection{Findings on $7^{\text {th }}$ grade coursebook and workbook}

In the $7^{\text {th }}$ grade social studies coursebook, social problems were mentioned in five units, being "Communication and Human Relations", "Population in Our Country", "Economy and Social Life", "Living Democracy", and "Bridges Between Countries", while the rest of the units did not include any reference to social problems.

Based on the social problems found in the $7^{\text {th }}$ grade social studies coursebook, four themes, which are environmental problems, population, health and war, were revealed. While the issues evaluated under the themes of environmental problems, health and war were given directly as social problems, those evaluated under the theme of population referred to social problems occurred due to the rapid growth of population. In this regard, it can be stated that the theme of population was not included in the coursebook as a social problem by itself, but the difficulties experienced as a result of the population growth such as immigration, unemployment and irregular urbanisation were considered as social problems. Besides, it was found that the social problems given under the theme of environmental problems in the coursebook such as immigration and natural disasters were emphasized to be the source of other social problems. As for the $7^{\text {th }}$ grade social studies workbook, it included activities related to the themes of environmental problems, health and population within the same units with the coursebook, but there were no activities related to the themes of health and war in the workbook, and five activities related to the other two themes were included.

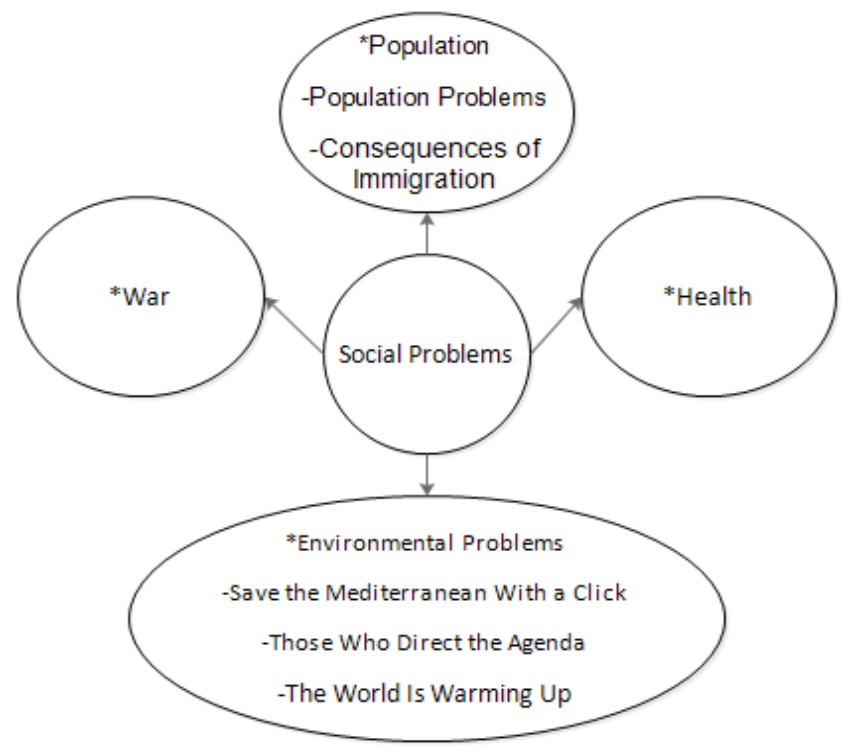

Figure 3. Social Problems Included in the $7^{\text {th }}$ Grade Coursebook and Workbook

Environmental problems was one of the themes revealed based on the social problems identified in the $7^{\text {th }}$ grade coursebook. In the coursebook, the social problems related to environmental pollution, destruction of forests, extinction of species and global warming were evaluated under the theme of environmental problems. The following statements presented in the unit "Bridges Between Countries" can be given as an example of the negative effect of global warming on species:

The extension of ice-free period with global warming causes hunger in polar bears living in the Arctic. The polar bears who couldn't find food have started to eat each other. Environmentalists point out that polar bears may become extinct until the end of this century with the melting ice caps due to global warming [55].

In addition, the same unit of the coursebook also included a topic titled "Global Warming" which explains that ice caps are melting due to climate change because of global warming, and the rise in sea levels as a result of this melting lead to the Hurricane Katrina in America. In the book, it was emphasized that a social problem can cause other local and global social problems by mentioning the deaths and other social problems such as contagious diseases, homelessness and economic difficulties as a result of the hurricane. In the $7^{\text {th }}$ grade workbook, the unit "Communication and Human 
Relations" included the Greenpeace actions within an activity titled "Save the Mediterranean with a Click" related to the theme of environmental problems, and the unit "Living Democracy" included the garbage problem within an activity titled "Those Who Direct the Agenda". Besides, the unit "Bridges Between Countries" included a piece of news titled "The World is Warming Up", a concept map and problem solving activities.

Health was another theme revealed based on the social problems identified in the $7^{\text {th }}$ grade coursebook. Under this theme, social problems related to contagious diseases were included in the unit "Bridges Between Countries". In the coursebook, the contagious diseases such as AIDS and malaria, and organisations fighting against these diseases such as the World Health Organization (WHO) were presented under the title of social problems. In the $7^{\text {th }}$ grade workbook, although there were no activities directly related to the health theme, the concept map activities of the environmental problems were associated with health.

Another theme revealed in the $7^{\text {th }}$ grade coursebook was the war theme. Under this theme, social problems experienced in World War I and afterwards presented in the unit "Bridges Between Countries" were included. In the coursebook, while it was told that war affect people as a social problem, how the difficulties experienced in war affect people was also mentioned with the statement "We lost thousands of our soldiers because of contagious diseases and cold" (p. 166) [55]. In the $7^{\text {th }}$ grade workbook, although there were activities included related to the war theme, these were in the intellectual dimension and no activities were included with regard to the social problems caused by war.

The last theme revealed from the $7^{\text {th }}$ grade coursebook was population. The social problems in the coursebook related to unemployment, irregular urbanisation, immigration, inadequate infrastructure, traffic problem and poverty were evaluated under the population theme. In the unit "Life on Earth" of the $7^{\text {th }}$ grade coursebook, the following statements were included to show what problems are experienced in human life as a result of rapid population growth:

The population of our major cities, particularly that of İstanbul, increases rapidly every passing day as a result of the imbalance in the distribution of population. Thus, our people living in cities face various problems. The main problems include unemployment, irregular urbanisation, inadequate infrastructure and traffic jam [55].

Besides, in the coursebook, it was emphasized that people have to immigrate due to rapid population growth with the statement "Some people move to another city or country from their birth place due to reasons such as meeting their economic needs and make their living" (p.44). In the unit "Population in Our Country" of the $7^{\text {th }}$ grade workbook, the activities "Population Problems" and "Results of Immigration" were included related to the population theme [56].

\subsection{Findings on the Coursebooks and Workbooks of the Ministry of National Education}

\subsubsection{Findings on $6^{\text {th }}$ grade coursebook and workbook}

Social problems were found to be mentioned in all the units of the $6^{\text {th }}$ grade social studies coursebook. Based on the social problems found in the coursebook, five themes, which are environmental problems, health, natural disasters, population and violation of human rights, were revealed. While the issues evaluated under the themes of environmental problems, health, population, and violation of human rights were given directly as social problems, those evaluated under the theme of natural disasters referred to social problems occurred due to natural disasters. In this regard, it can be stated that the theme of natural disasters was not included in the coursebook as a social problem by itself, but the difficulties experienced as a result of natural disasters were considered as social problems. As for the $6^{\text {th }}$ grade social studies workbook, it included activities related to the themes of environmental problems, health, natural disasters, and violation of human rights within the same units with the coursebook, but there were no activities related to the population theme in the workbook, and nine activities related to the other four themes were included.

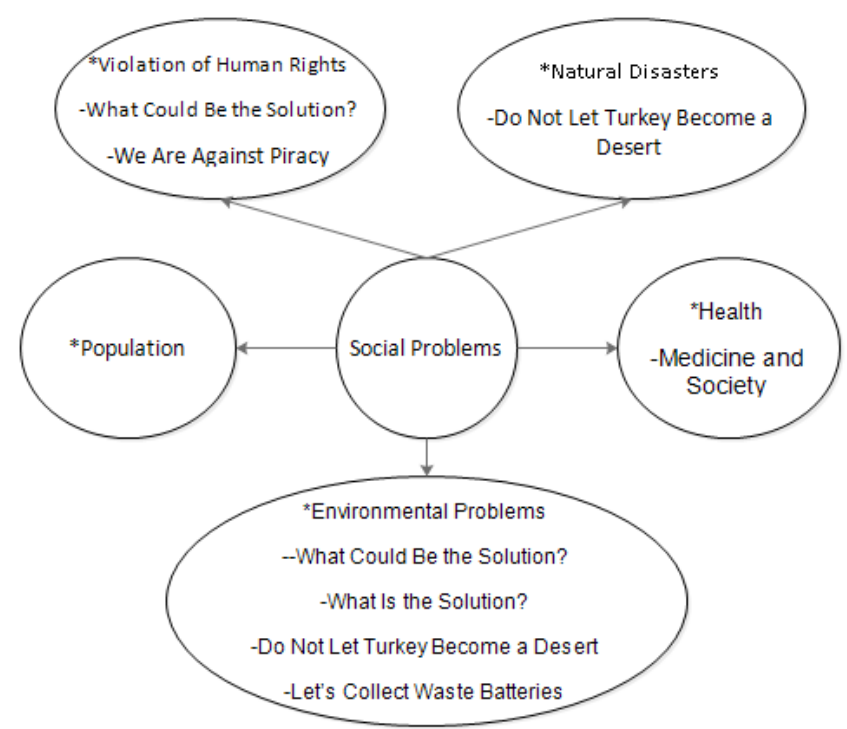

Figure 4. Social Problems Included in the $6^{\text {th }}$ Grade Coursebook and Workbook

Environmental problems were the first of the themes revealed based on the social problems identified in the 6th grade coursebook. In the coursebook, the social problems related to environmental pollution, unconscious use of natural resources, global warming, destruction of forests, and extinction of species were evaluated under the theme of environmental problems. In the 6th grade courseboook, this theme can be exemplified with the topic of how unconscious use of natural resources affects the life of species in a section titled "The World is Alarming" in the unit "Resources of Our Country", and the news titled "To Save the Black Sea" describing the rapid pollution growth in the Black Sea in the 
unit "Our Country and the World". As for the 6th grade workbook, it included the activities "What could be the solution?", "What is the solution?", "Do Not Let Turkey Become a Desert", "Town of Ulubey" and "Let's Collect Waste Batteries" in the units "I Learn Social Studies" and "Resources of Our Country" in parallel to the coursebook [58].

Health was another theme revealed based on the social problems identified in the 6th grade coursebook. These social problems related to contagious diseases, malignant diseases and need for blood were evaluated under the health theme. In the unit "Electronic Century" of the coursebook, the Crimean-Congo haemorrhagic fever (CCHF) and flu were mentioned, and the damages that these diseases cause in human life and the ways of protection from them were described [57]. Besides, it was emphasized in the same unit that the number of donors should increase gradually by attracting the attention to blood donation. In the $6^{\text {th }}$ grade workbook, the newspaper article titled "Medicine and the Society" was presented in the unit "Electronic Century" [58].

Another theme revealed in the $6^{\text {th }}$ grade coursebook was natural disasters. Under this theme, the unit "Our Country and the World" of the coursebook included the problems that masses experience after floods and earthquakes in various countries and the help sent by Turkey to these countries. The unit "Resources of Our Country" of the $6^{\text {th }}$ grade workbook included the activity "Do Not Let Turkey Become a Desert" related to erosion.

In the units "I Learn Social Studies", "Turks on the Silk Road", "Adventure of Democracy" and "Electronic Century" of the $6^{\text {th }}$ grade coursebook, the topics of violence against women, rights of disabled individuals, gender discrimination, wage theft, and discrimination were evaluated under the theme of violation of human rights. In the coursebook, it was emphasized that today, disabled individuals experience great difficulties due to architectural inadequacies, and individuals suffer from piracy. Besides, examples related to human rights were provided from the history, and the incidents of violence against women happened in the pre-Islamic period and the gender discrimination in pre-Republican period were mentioned. The $6^{\text {th }}$ grade workbook also included the activities titled "What Could Be the Solutions?" and "We Are Against Piracy" [58].

The last theme revealed from the social problems in the $6^{\text {th }}$ grade coursebook was population. Related to this theme, the traffic problem due to the rapid population growth was mentioned in the unit "I Learn Social Studies", and that various difficulties were experienced in the history because of the population growth and this growth caused immigration was given in the unit "Turks on the Silk Road". However, no activities were included in the $6^{\text {th }}$ grade workbook in this respect.

\subsubsection{Findings on $7^{\text {th }}$ grade coursebook and workbook}

Social problems were found to be mentioned in all the units of the $7^{\text {th }}$ grade social studies coursebook. Based on the social problems found in the $7^{\text {th }}$ grade social studies coursebook, seven themes, which are environmental problems, population, war, health, immigration, education, and violation of human rights, were revealed. While the issues evaluated under the themes of environmental problems, health, war, education and violation of human rights were given directly as social problems, those evaluated under the themes of population and immigration referred to social problems occurred due to the rapid growth in population and immigration. In this regard, it can be stated that the themes of population and immigration were not included in the coursebook as a social problem by themselves, but the issues such as unemployment and irregular urbanisation experienced as a result of the population growth and immigration were considered as social problems. As for the $7^{\text {th }}$ grade social studies workbook, it included activities related to the themes of environmental problems, immigration, health, war and population within the same units with the coursebook, but there were no activities related to the themes of education and violation of human rights in the workbook, and eight activities related to the other five themes were included.

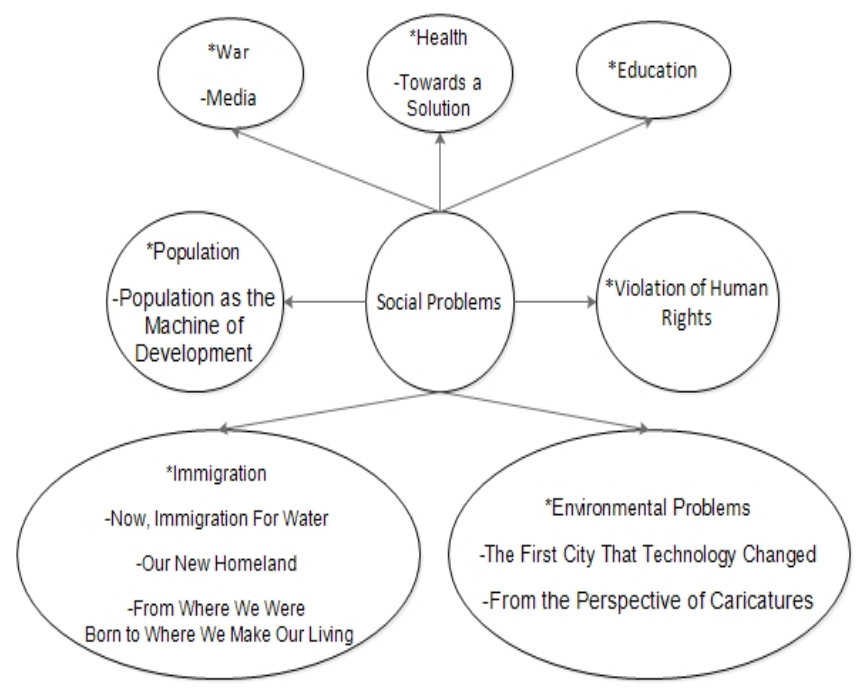

Figure 5. Social Problems Included in the $7^{\text {th }}$ Grade Coursebook and Workbook

Environmental problems was one of the themes revealed based on the social problems identified in the $7^{\text {th }}$ grade coursebook. In the coursebook, the social problems related to environmental pollution, destruction of forests, unconscious use of natural resources, global warming, and the resulting climate change and desertification were evaluated under the theme of environmental problems. In the unit "Living Democracy" of the $7^{\text {th }}$ grade coursebook, the text titled "Pollution Alert in Creek"(p. 158) under the topic "Environment Law Is the Concern of All of Us" can be shown as an example of social problems related to environmental problems. Besides, in the topic titled "Global Solutions to Global Problems" in the unit "Bridges Between Countries" of the coursebook, it was emphasized that environmental pollution is not only a national matter but also a global issue, and constitutes a major threat for the world by saying "Soil, 
water, air are all polluted rapidly, and the greenhouse gasses accumulated in the atmosphere cause global warming and climate change. In the process of climate change, more severe drought, floods, storms, contagious diseases and environmental pollution threaten our world" (p. 176) [59]. Similar to the coursebook, the 7th grade workbook also included the activity "The First City That Technology Changed" in the unit "Economy and Social Life" and preparing posters, drawing caricatures and problem solving tasks under the activity "From the Perspective of Caricatures" in the unit "Bridges Between Countries" [60].

Immigration was another theme revealed based on the social problems identified in the $7^{\text {th }}$ grade coursebook. Under this theme, the social problems that cause immigration and that are caused by immigration were dealt with, and ethnic and religious pressures and brain drain were mentioned. Besides, it was highlighted that population growth also caused immigration. The following statements presented in the unit "Population in Our Country" of the $7^{\text {th }}$ grade coursebook describe how the social problems caused by immigration affect human life:

Immigration from the countryside leads to population growth in cities. The rapid growth of population causes housing shortage. The settlement areas expand as a result of immigration, and industrial facilities becomes part of the city. The agricultural fields in the immediate environment start to be used for different purposes. As is seen in the photograph on the left hand side, the traffic get busier. Schools and hospitals can no longer meet the demand. Investments towards population growth also become a burden for the country's economy [59].

At the same time, the social problems that cause immigration were also provided in the coursebook. With respect to immigration, the coursebook provided the following statements:

With the Lozan Treaty following the War of Independence, the population exchange aggreement was signed between Turkey and Greece. Accordingly, Turks migrated from Greece to Turkey, and Greeks from Turkey to Greece. Due to regime, ethnic and religious pressures, a number of our compatriots living in the Balkans migrated to Anatolia [59].

In these statements, the issue of population exchange was explained, and it was emphasized that elements such as terrorism, war, ethnic and religious pressures, and regime also cause immigration. As for the $7^{\text {th }}$ grade workbook, it included the activities titled "Now, Migration for Water" and "Our New Homeland", and a performance project titled "From where we were born to where we make our living" [60].

Population was another theme revealed from the $7^{\text {th }}$ grade coursebook. The social problems in the coursebook related to unemployment, irregular urbanisation, immigration, inadequate infrastructure, traffic problem and poverty were evaluated under the population theme. These themes were also associated with the immigration theme. In the unit "Population of Our Country" of the $7^{\text {th }}$ grade coursebook, it was emphasized that population growth also causes other social problems by saying "The world's population, which gets close to seven billion people, continues to grow rapidly. Rapid population growth and the consequent increase in consumption drain the natural resources of the world as well as cause many global problems" (p. 45) [59]. In addition, it was highlighted that the rapidly growing population in Turkey also causes the unemployment problem. Based on these examples, it can be stated that students' interest was attracted both national and global problems with regard to the population theme in the coursebook. Moreover, the unit "Population of Our Country" of the $7^{\text {th }}$ grade workbook included an activity titled "Population as the Machine of Development".

Another theme revealed in the $7^{\text {th }}$ grade coursebook was the war theme. The social problems due to the wars and civil wars throughout the history as well as terrorism, and class and boundary conflicts were evaluated under the war theme. In the coursebook, it was mentioned that war and terrorism are global social problems and have serious effects on people. Besides, the United Nations, which was found to ensure international peace and security, was also mentioned. As for the $7^{\text {th }}$ grade workbook, although there were no activities directly related to the war theme, the problems caused by war were mentioned in an activity titled "Media" in the unit "Communication and Human Relations".

In the $7^{\text {th }}$ grade coursebook, women and child workers, colonialism, slavery, and gender discrimination were evaluated under the theme of violation of human rights. In the unit "Economy and Social Life" of the coursebook, it was stated that the working class that emerged with the industrial revolution caused various social problems, and the number of women and child workers increased every other day. In addition, while elaborating on history in the same unit, colonialism and people who worked as slaves were also mentioned. However, no activities were included in the $7^{\text {th }}$ grade workbook with respect to this theme.

Health was another theme revealed based on the social problems identified in the $7^{\text {th }}$ grade coursebook. The social problems related to contagious diseases and death were evaluated under this theme. In the coursebook, it was pointed out that contagious diseases like AIDS and malaria are a global social problem. As for the $7^{\text {th }}$ grade workbook, the activity titled "Towards the Solution" was included, and that the average life expectancy is 32 years in Swaziland due to the HIV virus and tuberculosis.

The last theme revealed from the $7^{\text {th }}$ grade coursebook was education. In the unit "Population of Our Country" of the coursebook, the social problems due to girls' not being sent to school and the literacy rate were included in related to the education theme. However, these problems were not dealt with separately, but it was mentioned that they were social problems. On the other hand, no activities were included in the $7^{\text {th }}$ grade workbook in this respect. 
During the research process, it was observed that the techniques used related to social problems showed variation across the publishers. Whereas the workbooks published by private publishing companies included activities such as preparing posters, question-answer, crossword puzzles, problem solving, and preparing projects, the workbooks of the Ministry of National Education were observed to contain, in addition to those in the private publishers' books, activities of fish bone, composition writing and newspaper articles.

\subsection{Comparison of the Courseboks and Workbooks of the Ministry and Private Publishers in terms of their Inclusion of Social Problems}

As is shown in Table 1, the social studies coursebooks and workbooks published by the Ministry and the private publishing firms were different from each other in terms of their inclusion of social problems. In the coursebooks and workbooks that were prepared based on the same curricula, there were eight units in $5^{\text {th }}$ grade, seven units in $6^{\text {th }}$ grade and seven units in $7^{\text {th }}$ grade. It was found that in the $5^{\text {th }}$ grade coursebooks and workbooks, social problems were included in five of the eight units, and these five units contained the themes of education, health, natural disasters, and environmental problems. Since only the coursebook and workbook published by a private firm, Evren Publishing, was used in $5^{\text {th }}$ grade, it was not possible to make a comparison between the books of the private publishers and the Ministry for this grade level.

In the $6^{\text {th }}$ grade coursebooks and workbooks, there are seven units in total. Those of the private firms included social problems in five of these seven units, and these five units contained four themes, which were environmental problems, health, natural disasters, and human rights. On the other hand, those of the Ministry included social problems in all of the seven units, and in addition to the themes in the private firm counterparts, the books of the ministry also touched upon the population theme and thus contained five themes. In this regard, it can be stated that the coursebook and workbook of the Ministry included more themes related to social problems in more units compared to those of the private firms.

The $7^{\text {th }}$ grade social studies coursebooks and workbooks included seven units. Those of the private firms incorporated social problems in five of these seven units, and these five units had four themes, which were environmental problems, health, population, and war. On the other hand, those of the Ministry included social problems in all of the seven units, and in addition to the themes contained in the books of the private firms, the books of the ministry also had themes of violation of human rights, immigration, and education, and thus, contained a total of seven themes. Therefore, it can be said that the coursebook and workbook of the Ministry included more themes related to social problems in more units compared to those of the private firms.

Table 1. Comparison of the coursebooks and workbooks in terms of social problems

\begin{tabular}{|c|c|c|c|c|c|c|}
\hline \multirow[t]{2}{*}{ Grade } & \multicolumn{3}{|c|}{ Coursebooks and Workbooks of Private Publishers } & \multicolumn{3}{|c|}{ Coursebooks and Workbooks of the Ministry } \\
\hline & Number of Units & $\begin{array}{l}\text { Number of Units } \\
\text { Including Social } \\
\text { Problems }\end{array}$ & $\begin{array}{c}\text { Number of } \\
\text { Themes Related } \\
\text { to Social } \\
\text { Problems } \\
\end{array}$ & Number of Units & $\begin{array}{l}\text { Number of Units } \\
\text { Including Social } \\
\text { Problems }\end{array}$ & $\begin{array}{c}\text { Number of Themes } \\
\text { Related to Social } \\
\text { Problems }\end{array}$ \\
\hline $5^{\text {th }}$ & 8 & 5 & 4 & 8 & 5 & 4 \\
\hline $6^{\text {th }}$ & 7 & 5 & 4 & 7 & 7 & 5 \\
\hline $7^{\text {th }}$ & 7 & 5 & 4 & 7 & 7 & 7 \\
\hline
\end{tabular}




\section{Results, Discussion and Suggestions}

Based on the findings obtained from the social studies coursebooks and workbooks published by private publishing companies, four themes were revealed from the social problems given in all grade levels. In this sense, the themes of education, health, natural disasters and environmental problems were found in the $5^{\text {th }}$ grade coursebook and workbook, the themes of environmental problems, health, natural disasters and violation of human rights in the $6^{\text {th }}$ grade coursebook and workbook, and the themes of environmental problems, population, health and war in the $7^{\text {th }}$ grade coursebook and workbook. In addition to the four themes revealed in each grade level, five activities were included in the $5^{\text {th }}$ grade workbook, six activities in the $6^{\text {th }}$ grade workbook, and five activities in the $7^{\text {th }}$ grade workbook. While the themes of education, health, violation of human rights and war were regarded directly as social problems in the social studies coursebooks and workbooks of the private publishers, it was emphasized that the themes of natural disasters, environmental problems and population were not social problems by themselves, but they were causes to other social problems.

Based on the findings obtained from the social studies coursebooks and workbooks published by the Ministry, four themes were revealed in $5^{\text {th }}$ grade, five themes in $6^{\text {th }}$ grade, and seven themes in $7^{\text {th }}$ grade. Social problems were found to be shaped by the themes of education, health, natural disasters and environmental problems in the $5^{\text {th }}$ grade coursebook and workbook, the themes of environmental problems, health, natural disasters, population and violation of human rights in the $6^{\text {th }}$ grade coursebook and workbook, and the themes of environmental problems, population, war, health, immigration, education and violation of human rights in the $7^{\text {th }}$ grade coursebook and workbook. In addition, based on the grade levels, five activities were included in the $5^{\text {th }}$ grade workbook, nine activities in the $6^{\text {th }}$ grade workbook, and eight activities in the $7^{\text {th }}$ grade workbook. While the themes of education, health, violation of human rights and war were regarded directly as social problems in the social studies coursebooks and workbooks published by the Ministry, it was emphasized that the themes of natural disasters, environmental problems, immigration and population were not social problems by themselves, but they were causes to other social problems.

Comparing the themes and activities of social problems in the coursebooks and workbooks of the private publishers and the Ministry, it was found that the books published by the Ministry gave wider coverage to social problems than those published by the private publishers. Besides, the books of the Ministry included more activities and more diverse themes than those of the private publishers. For example, although immigration was covered in the books by both types of publishers as a topic, those of the private publishers did not regard immigration as a social problem, whereas the books of the Ministry presented immigration as well as its causes and results as a social problem.
With respect to poverty, Yakar [43] found that it was included as a social problem in the unit "Bridges Between Countries" of the 7th grade social studies coursebook, while Adalar [1] revealed that it was not included as a social problem in the social studies coursebooks. Therefore, the results of this study and other studies in the literature show differences. Moreover, this study is also different in terms of examining the social problems in workbooks in addition to coursebooks.

The workbooks of both types of publishers also showed differences in terms of the activities they included. The workbooks of the private publishers mostly included activities such as newspaper articles, concept maps, preparing posters, crossword puzzles, preparing projects and problem solving, whereas those of the Ministry included, in addition, activities such as fish bone and composition writing.

In the coursebooks of both types of publishers, social problems were found to be included in both national and global contexts. Similar to this result of the study, Yakar [43] also revealed that poverty was dealt with in both global and national contexts. Besides, social problems were not only included within current events, but also events in the history. However, it was also found that some of the examples given during the presentation of certain topics were repeated in different grade levels.

In the study, the social studies coursebooks and workbooks of the private publishers were determined to include less social problems than those of the Ministry did. Based on this result, it can be suggested that private publishing companies should give more coverage to social problem in their social studies coursebooks and workbooks. Besides, there were fewer explanations related to social problems in the explanation section of the social studies curricula, when considered how social problems were included in the social studies coursebooks. In the study, it was found that the examples towards social problems were repetitive in the coursebooks. Therefore, examples should be made diverse. In addition, the social problems in the social studies coursebooks and workbooks should be updated and made more interesting.

\section{REFERENCES}

[1] H. Adalar. Bağımlılık ve Bağımlılar. In: A. Ocal, editor. Dezavantajlı Gruplar ve Sosyal Bilgiler Öğretimi. Pegem Akademi, Ankara, 2015, 142-170.

[2] N. Adak. Sosyoloji ve Sosyal Problemler. In: N. Adak (Ed.), Sosyal Problemler Sosyolojisi. Ankara: Siyasal Kitabevi. 2009, 15-34.

[3] A. Altınok. Sosyal Katılım Faaliyetlerinin 12-14 Yaş Grubu Öğrencilerinin Sosyal Problemlere Olan Duyarlılıklarına Etkisi. Unpublished Master Thesis, Aksaray Üniversitesi, Aksaray, 2012. 
[4] A. Altun. Yapılandırmacı Yaklaşım, Sosyal Bilgiler Programları ve Ders Kitapları. In: B. Akbaba (Ed.), Konu Alanı Ders Kitabı Inceleme Kılavuzu Sosyal Bilgiler. Pegem Akademi, Ankara, 1-28, 2013.

[5] P. Archer. Towards a Theory of Interest Claims in Constructing Social Problems, Qualitative Sociology Review, Vol.11, No: 2, 47-60, 2015.

[6] P. J. Barber, K. K. Walczak. Conscience and Critic: Peer Debriefing Strategies in Grounded Theory Research. American Educational Research Association (AERA), California, 1-19, 2009.

[7] A. B. I. Bernardo, J. H. Liu. Sharpening Our Understanding of Social Problems in Asian Societies: The Roles of Culture and Theory in Socially Engaged Social Psychology. Journal of Pasific Rim Pschology. Vol. 9, No: 2, 43-49, 2015.

[8] I. Boldiş. Youth Transition from Care to Independent Adulthood: A Social Problem?, Revista de Asistența Sociala. Vol: 13, No: 4, 101-119, 2014

[9] Ş. Büyüköztürk, E. Kılıç Çakmak, Ö. E. Akgün, Ş. Karadeniz, F. Demriel. Bilimsel Araştırma Yöntemleri. (Extended 12. Edition). Pegem Akademi, Ankara, 2012.

[10] Ö. Demirel, K. Kıroğlu. Eğitim ve Ders Kitapları. In: Ö. Demirel, K. Kıroğlu (Eds.), Konu Alanı Ders Kitabı İncelemesi, Pegem Yayıncilık, Ankara, 1-11, 2005.

[11] Z. Eisikovits, C. Koren, T. Band-Winterstein. The Social Construction of Social Problems: The Case of Elder Abuse and Neglect. International Psychogeriatrics, Vol: 25, No: 8, 1291-1298, 2013.

[12] Ö. Eryılmaz. Sosyal Bilgiler Derslerinde Güncel Olaylardan Yararlanmanın Öğrencilerin Sosyal Problemlere Duyarlılıklarına Etkisi. Unpublished Master Thesis, Anadolu University, Eskişehir, 2015.

[13] V. A. Ferrer-Perez, E. Bosch-Fiol. Gender Violence as a Social Problem in Spain: Attitudes and Acceptability, Sex Roles, Vol: 70, 506-521. 2014.

[14] C. A. Fogel. Social Problems in Canadian Ice Hockey: An Exploration through Film. Physical, Culture and Sport Studies and Research. Vol: 64, 64-70, 2014.

[15] E. Friesem. Dialogue on Media Representations of Social Problems: Enhancing Civic Engagement by Uncovering Implicit Knowledge Accumulated from the Media, Journal of Communication Inquiry, Vol: 40, No: 1, 46-66, 2016.

[16] S. F. Hassane, A. S. Abdullah. Exploring the most Prevalent Social Problems in the United Arab Emirates. International Journal of Academic Research, Vol: 3, No: 2, 572-577, 2011.

[17] N. Jarrett, I. Scott, J. Addington-Hall, Z. Amir, S. Brearley, L. Hodges, A. Richardson, M. Sharpe, Z. Stamataki, D. Stark, C. Siller, L. Ziegler, C. Foster. Informing Future Research Priorities into the Psychological and Social Problems Faced by Cancer Survivors: A Rapid Review and Synthesis of the Literature, European Journal of Oncology Nursing, Vol: 17, 510-520, 2013.

[18] S. Kızılçelik. Sanayileşme ve Kentleşme Süreci ile Ortaya Çıkan Bazı Sosyal Problemlerin Suça Etkisi Üzerine Sosyolojik Düzeyde Teorik Bir Çalışma. Unpublished Master Thesis, Hacettepe Üniversitesi, Ankara, 1991.
[19] W. Kornblum, J. Julian. Social Problems (Seventh Edition). Prantice Hall, New Jersey, 1991.

[20] B. O. Larsen, L. Jensen, T. P. Jensen. Transitions in Secondary Education: Ex4ploring Effects of Social Problems, Research in Social Stratification and Mobility, Vol. 38, 32-42, 2014.

[21] T. Lemoyne, J. M. Davis. Debunking Common Sense and the Taken For Granted: A Pedagogical Strategy for Teaching Social Problems, Teaching Sociology, Vol: 39, No: 1, 103-110, 2011.

[22] A. Leon-Guerrero. Social Problems: Community, Policy, and Social Action, Pine Forge Press, California, 2005.

[23] J. J. Macionis. Social Problems (Sixth Edition), Pearson, 2015.

[24] J. N. Maples, W. V. Taylor. Writing Children's Books in Sociology Class: An Innovative Approach to Teaching Social Problems to Undergraduate Students, International Journal of Teaching and Learning in Higher Education, Vol: 25, No: 3, 358-368, 2013.

[25] A. Mardache. Community of Predeal a Diagnosis of Social Problems. Bulletin of the Transilvania University of Braşov, Vol: 3, No: 52, 34-40, 2010.

[26] MEB (2005). Sosyal Bilgiler 4.-5. Sinıf Programı. Talim ve Terbiye Kurulu Başkanlığı. Online available from $\mathrm{http}: / / \mathrm{ttkb} . \mathrm{meb}$. gov.tr/program2.aspx?islem=2\&kno=39.

[27] D. Michailakis, W. Schirmer. Social Work and Social Problems: A Contribution from Systems Theory and Constructionism. International Journal of Social Welfare, Vol: 23, 431-442, 2014.

[28] M. Morris. Linking Social-Problem Models to Needs-Assessment Methodology in the Teaching of Evaluation, The American Sociologist, 2015, Online available from http://link.springer.com/article/10.1007\% $2 \mathrm{Fs}$ 12108-015-9265-x .

[29] E. Neiterman. Constructing and Deconstructing Teen Pregnancy as a Social Problem, Qualitative Sociology Review, Vol: 8, No: 3, 25-47, 2012.

[30] M. A. Nissen. In Search for Sociology of Social Problems for Social Work. Qualitative Social Work, Vol: 13, No: 4, 555-570, 2014.

[31] Nordik Council for Alcohol and Drug Research. Journalists, Administrators and Business People on Social Problems: A Study around Baltic Sea. In: S. Hanhinen, J. Törrönen (Eds.), NAD Publication, Helsinki, 1998.

[32] A. Öcal, H. Demirkaya, A. Altınok. İlköğretim Öğrencilerine Yönelik Sosyal Duyarlılık Ölçeğinin Geliştirilmesi. Pegem Journal of Education and Instruction, Vol: 3, No: 1, 67-76, 2013.

[33] A. V. Pashkevich. Upper-Grade Students' Attitudes toward Social Problems. Russian Social Science Review, Vol: 52, No: $5,25-33,2011$

[34] F. Poletta, C. Tomlinson. Date Rape After The Afterschool Special: Narrative Trends in the Televised Depiction of Social Problems, Sociological Forum, Vol: 29, No: 3, 527-548, 2014

[35] C. B. Sanders, T. Christensen, C. Weston. Constructing Crime In A Database: Big Data and the Mangle of Social Problems Work, Qualitative Sociology Review, Vol: 11, No: 2, 
$181-195,2015$.

[36] W. Scott, Y. Suh. Standardizing the Essential Knowledge, Skills, and Attitudes for Democratic Life: A Content Analysis of Virginia Standards of Learning and Social Studies Textbooks, the Social Studies, Vol: 106, No: 3, 92-103, 2015.

[37] I. Skreitule-Pikše, I. Bite, M. Raščevska, S. Sebre, A. Kolesovs, I. Damberga, B. Martinsone. Social Problems of Children with Language Impairment: Associations with Other Behavioral Problems, Adaptive Behavior, and Intellect. Baltic Journal of Psychology, Vol: 15, No: 1,2, 73-86, 2014.

[38] Ü. Şentürk. Parçalanmış Aile Çocuk Ilişkisinin Sebep Olduğu Sosyal Problemler (Malatya Uygulamas1),Unpublished Dissertation, İnönü Üniversitesi, Malatya, 2006.

[39] N. Tertemiz, L. Ercan, Y. Kayabaşı. Ders Kitabı ve Eğitimdeki Önemi. In: L. Küçükahmet (Ed.), Konu Alanı Ders Kitabı İnceleme Kılavuzu, Nobel Yayıncılık, Ankara, 34-66, 2011.

[40] A. Thio, J. Taylor. Social Problems, Jones\&Barlett Learning, Ontario, 2012.

[41] A. H. Van Houwelingen, W. P. J. Den Elzen, S. le Cessie, , J. W. Blom, J. Gussekloo1. Consequences of Interaction of Functional, Somatic, Mental and Social Problems in Community-Dwelling Older People. Plos One, Vol: 10, No: 4, $1-11,2015$.

[42] I. Vardi. Quanifying Accidents: Cars, Statistics, and Unintended Consequences in the Construction of Social Problems over Time. Qual Sociol, Vol: 37, 345-367, 2014.

[43] H. Yakar. Yoksulluk. In: A. Öcal (Ed.), Dezavantajlı Gruplar ve Sosyal Bilgiler. Pegem Akademi, Ankara, 18-41, 2015.

[44] A. Yıldırım, H. Şimşek. Sosyal Bilimlerde Nitel Araştırma Yöntemleri. ( $9^{\mathrm{TH}}$ Extended Edition), Seçkin Yayıncılık, Ankara, 2013.

[45] N. Zafar, R. Kausar. Emotional and Social Problems in Divorced and Married Women, FWU Journal of Social Sciences, Vol: 8, No: 1, 31-35, 2014.

[46] F. Zayimoğlu Öztürk. Engelliler ve Engellilik. In: A. Öcal (Ed.). Dezavantajlı Gruplar ve Sosyal Bilgiler. Pegem Akademi, Ankara, 46-68, 2015.
[47] A. Öztürk, E. Akdanoğlu. Küresel Problem. In:N. Adak (Ed.), Sosyal Problemler Sosyolojisi, Siyasal Kitabevi, Ankara, 67-97.

[48] J. M. Ostrow. Social Sensitivity: A Study of Habit and Experience, Unpublished Dissertation, Boston University, Boston, 1988.

[49] A. Hassan, E. A. Blood, A. Pikcilingis, E. G. Krull, L. McNickles, G. Marmon, S. Wylie, E. R. Woods, E. W. Fleegler. Youths' Health-Related Social Problems: Concerns Often Overlooked During the Medical Visit. Journal of Adolescent Health, Vol: 53, 265-271, 2013.

[50] G. A. Bowen. Document Analysis as a Qualitative Research Method. Qualitative Research Journal, Vol: 9, No: 2, 27-40, 2009.

[51] E. Ü. Karabıyık. İlköğretim Sosyal Bilgiler 5 Ders Kitabı. Evren Yayıncılık, Ankara, 2014.

[52] E. Ü. Karabıyık. İlköğretim Sosyal Bilgiler 5 Öğrenci Çalıșma Kitabı. Evren Yayıncılık, Ankara, 2014.

[53] Z. Tekten. İlköğretim Sosyal Bilgiler 6 Ders Kitabı. Yakınçağ Yayınları, Ankara, 2015.

[54] Z. Tekten. İlköğretim Sosyal Bilgiler 6 Öğrenci Çalışma Kitabı. Yakınçağ Yayınları, Ankara, 2015.

[55] S. Tüysüz, S. Yıldırım. İlköğretim Sosyal Bilgiler 7 Ders Kitabı. Tuna Matbaacılık, Ankara, 2010.

[56] S. Tüysüz, S. Yıldırım. İlköğretim Sosyal Bilgiler 7 Öğrenci Çalışma Kitabı. Tuna Matbaacılık, Ankara, 2010.

[57] Milli Eğitim Bakanlığı. İlköğretim Sosyal Bilgiler 6 Ders Kitabı. MEB Yayınları, Ankara, 2015.

[58] Milli Eğitim Bakanlığı. İlköğretim Sosyal Bilgiler 6 Öğrenci Çalışma Kitabı. MEB Yayınları, Ankara, 2015.

[59] Milli Eğitim Bakanlığı. İlköğretim Sosyal Bilgiler 7 Ders Kitabı. MEB Yayınları, Ankara, 2015.

[60] Milli Eğitim Bakanlığı. İlköğretim Sosyal Bilgiler 7 Öğrenci Çalışma Kitabı. MEB Yayınları, Ankara, 2015. 